\title{
NEW LABOUR AND SCHOOL LEADERSHIP 1997-2007
}

\author{
by Helen Gunter and Gillian Forrester, University of Manchester
}

\begin{abstract}
We draw on empirical data and theorising that focuses on the relationship between the state, public policy and knowledge in the construction and configuration of school leadership under New Labour from 1997. Specifically we show how a school leadership policy network comprises people in different locations who operate as policy entrepreneurs in shaping policy.
\end{abstract}

Keywords: School leadership, education policy, New Labour, policy entrepreneurs

\section{INTRODUCTION}

Investment in particular knowledge claims and production processes for school leadership is a major thrust of New Labour public policy in England. This emphasis on leadership as a way of organising schools and securing national reforms is an important site for examining the relationship between the state, public policy and research knowledge. In this paper we focus on the types of knowledge within policy texts, the ways of knowing that are privileged and the knowers who have influenced and shaped the use and promotion of knowledge and knowing about school leadership. We do this by drawing on data and analysis from the ESRC funded Knowledge Production in Educational Leadership (KPEL) project, where we have undertaken a study of written texts in the form of policy documents together with oral texts based on interviews with what we call a school leadership policy network made up of ministers, civil servants, advisors and consultants directly involved in the construction and implementation of policy.

We present a critical policy scholarship of New Labour and school leadership within the trajectory described by Deem et al. (1995) as a 'policy turn', where the politicisation of education through successive modernisation agendas led to studies that examine the power structures at work within policymaking. Notably we frame the New 
Labour strategy as based on regulating the risk of reform implementation at local level through centralised interventions devised and implemented by a school leadership policy network who operate as, what Kingdon (2003) calls, policy entrepreneurs. The written and oral texts reveal a delivery disposition (Bourdieu, 1990) within the professional practice of these policy entrepreneurs, particularly through a control imperative in the relationship between policy and practice.

\section{Critical Policy Scholarship}

When New Labour came to power in 1997 it inherited a commitment from previous Conservative governments to improve standards and tackle school failure (DES, 1985; Joseph, 1984). The New Right had pursued a combination of site-based management within a quasimarket, with a regulatory regime consisting of the National Curriculum, testing, league tables and inspection. New Labour extended the scope and strengthened the intensity of regulation by focusing on the headteacher rather than teachers, not least because 24,000 headteachers were easier to direct compared with over 400,000 teachers. The strategy was: first, establishing national standards which explicitly framed the headteacher and their work as transformational leadership, with a responsibility to deliver national reforms (DfES, 2004a); second, controlling knowledge production through directly commissioning research based on policy priorities and establishing a National College for School Leadership (NCSL) to lead debate (Hopkins, 2001), use school effectiveness and improvement research (Leithwood et al., 2006), and to follow a prescriptive remit to deliver national policy (see Kelly, 2004); third, establishing a national framework of performance management and pay based on training, accreditation and licensing combined with targets and inspection (DfEE, 1998). The National Ministry (currently known as the Department for Children, Schools and Families, DCSF) together with the NCSL as its delivery arm, and contracted consultants such as PricewaterhouseCoopers (e.g. DfES/PwC, 2007), control what is known, what should be known and why it is worth knowing.

Leadership research tends to be commissioned by the DCSF or the NCSL where the remit and outcomes are strictly controlled. While there are important analyses from both inside (e.g. Barber, 2007; Blunkett, 2006; Hyman, 2005) and outside the government (e.g. Ball, 2007; Chitty, 2004; Tomlinson, 2005), there is little independently funded research into the relationship between public policy and knowledge production focusing on school leadership 
(Gunter and Fitzgerald, 2008; Weindling, 2004). Knowledge producers doing commissioned research (from within the public and private sectors) are treated as problem solvers rather than problem posers, or what Thrupp and Willmott identify as 'textual apologists' (2003, p. 7) who provide policy science techniques and/or sell their solutions in ways that enable practice to be changed 'into an image of policy' (Ball, 1995, p. 265). The KPEL Project is a response to this limited view, and seeks to investigate the way knowledge production operates at a time of New Labour modernisation of education, with a particular emphasis on the relationship between the state, public policy and knowledge.

This paper will report on a particular aspect of the Project by drawing on data from, first, a critical analysis of policy texts such as speeches, white and green papers and legislation; and second, agreed oral texts based on 33 interviews with a purposive sample drawn from Whitehall, universities, schools, and private sector consultancies. This includes three interviews with former Secretaries of State for Education (one Conservative and two New Labour); five civil servants, three who have been directly involved in the formation and implementation of school leadership policy, including the setting up of the NCSL; six former and current members of government agencies such as the NCSL, and the Specialist Schools and Academies Trust (SSAT); eight people who have been brought into the Department from higher education, schools, and local authorities to either take up a full time advisory role or provide advice for the Ministry, or agencies such as the NCSL, when called upon; three Directors of Training Centres established as cost centres in Universities to provide national training programmes for the NCSL; eight private sector consultants (from the UK and abroad, mainly North America and Australia) who have advised on strategy at the highest levels of government, undertaken major research and produced policy advice reports, through to those who are contracted to deliver school leadership policy such as training programmes. Three of the private consultants work for major international companies, two head their own UK based company, and three operate alone or in a partnership.

The interviewees remain anonymous and are labelled by their current role, and this enables the range of people together with the impact of their particular employment location to be recognised. All have been or are directly involved in the construction, promotion and delivery of school leadership as a model and form of professional practice, and we identify these people as part of a school leadership policy network. To speak of these people as a 'network', to some extent affects their uniqueness in terms of the role they play. To draw 
attention to and discuss their specific activities and functions, however, would most likely result in them being identifiable. Generically they present themselves as knowledgeable and so occupy the position of 'knowers' about school leadership. They are either appointed to particular advisory roles in government or are contracted to support those in these roles through advice, strategies, ideas and delivery. They have strong links of association through coming to know each other, for instance through previous projects, and over time inter-dependency has grown. The conditions in which they work and earn their salaries share high levels of risk: those in formal government roles face the risk of policy failure and those in private companies face the risk of contractual loss. All have a stake in making policy successful and they construct the means by which this will be judged through target delivery combined with controlling the knowledge production processes that legitimise the technology of good practice.

The interviews took place between spring 2006 and summer 2007, and all interviews were recorded, transcribed and the text returned to the interviewee for checking. In addition to asking respondents to tell us about themselves, their role and interest in education policy, we asked each person to talk about: first, the purposes of New Labour education policy; second, the gains from and concerns about policy; third, the approach to school leadership that they perceive to be central to policy and their views on this; and fourth, the role of the NCSL and their views on the contribution made by the College, together with concerns about its purposes and impact. Like Ball (1990) we are unable to quote directly from everyone, but we have used their contribution to develop themes and patterns about attitudes and perceptions of this school leadership policy network.

Our intention is to position the paper as an example of critical policy scholarship (Ball, 1990; Grace, 1995; Ozga, 2000) based on Ozga's (1987, p. 14) definition of research 'rooted in the social science tradition, historically informed and drawing on qualitative and illuminative techniques'. Hence the approach taken is different from research that aims to measure whether leadership is working and develop strategies for how it might work better (see Currie $e t a l$., 2005). Instead we aim to get inside the policy process to examine the assumptions, attitudes and approaches of the people who make it and do it. The school leadership policy network straddles the interface between policy intention (process of formulation) and policy outcomes (process of implementation), and so the paper is concerned with the way interests align and dispositions are revealed through formal (e.g. tendering processes) and informal 
(e.g. trust) contracts. The types of argument that are made for the major investment in school leadership are presented, and the types of discourse used to frame what is known about school leadership and what it can achieve are examined. Notably we are, like Ball (1994, p. 171), concerned with 'real world issues', and we are mindful that 'policies are not totalizing' (p. 177), and so we are able not only to give our attention to a major issue of practice and policy, but also to recognise that there are spaces where there can be opportunities to speak back to policy. We do not intend to use a positivist template by presenting a literature review, followed by a methodology and findings, but to act as 'cultural critics offering perspective rather than truth' (Ball, 1995, p. 268). We do this through the use of theory as 'a tool for exploration and for thinking otherwise' (p. 268), and we admit that there are important issues of 'complexity, uncertainty and doubt' (p. 269) in relation to knowledge claims, not least because in the wider field there remains a range of knowledge, ways of knowing and a variety of knowers (Gunter, 2005).

\section{Effective School Leadership}

Figure 1 is a summary of the beginning and end of the first decade of New Labour's school leadership strategy based on our reading of the written and oral texts.

New Labour promoted the argument that effective headship is through the headteacher as school leader with the right attributes, behaviours and knowledge. Interviewees talked about the normality of headteachers as leaders, and how they had accepted the evidence that headteachers make the difference. As one Minister stated:

So you come to government with anecdotal evidence that heads make a difference, and if you look at ... what we were being given from OfSTED and the rest of it seemed to show that leadership makes a difference ... I don't think we made a decision that we'd concentrate on leadership, there was not a point when that decision was made, it was obvious ...

The dominance of former practitioners in government or as advisors and consultants meant that New Labour intuitively realised it was a means of achieving changes in attitudes and practice.

This discourse is evident in policy and oral texts around the notion of school leadership in terms of authoritative explanations, together with the proposed course of action. In Excellence in Schools New Labour states: 


\begin{tabular}{|c|c|c|}
\hline Official Label & School Leaders & Effective Leaders \\
\hline \multirow{2}{*}{$\begin{array}{l}\text { Preferred } \\
\text { model }\end{array}$} & Transformational leadership & Transformational \\
\hline & $\begin{array}{l}\text { to deliver national reforms } \\
\text { in the school. }\end{array}$ & $\begin{array}{l}\text { leadership to deliver } \\
\text { national reforms locally. }\end{array}$ \\
\hline Leader & Headteacher as chief executive. & $\begin{array}{l}\text { School/Academy/Federation/ } \\
\text { Systemic leader as chief } \\
\text { executive and networker }\end{array}$ \\
\hline \multirow[t]{4}{*}{ Leading } & $\begin{array}{l}84 \text { National Standards: } 16 \\
\text { relate to knowledge; } 35 \text { relate } \\
\text { to skills and attributes; and }\end{array}$ & $\begin{array}{l}149 \text { National Standards } \\
\text { across } 6 \text { key areas of } \\
\text { Headteacher role: } 49\end{array}$ \\
\hline & 33 ways in which heads & relate to knowledge; \\
\hline & $\begin{array}{l}\text { impact on five areas of } \\
\text { strategic direction of the }\end{array}$ & 52 to professional \\
\hline & school (TTA, 1998). & actions (DfES, 2004b). \\
\hline \multirow[t]{6}{*}{ Leadership } & Headteacher as inspirational and & School/Academy/Federation/ \\
\hline & influential in communicating & Systemic leaders to lead \\
\hline & and building commitment with & reforms locally and nationally \\
\hline & followers in school and the & $\begin{array}{l}\text { through inspiration and } \\
\text { influence within distributed }\end{array}$ \\
\hline & & networks. Build commitment \\
\hline & & $\begin{array}{l}\text { with followers within a diverse } \\
\text { workforce and community. }\end{array}$ \\
\hline Key features & Effective headship as measured & Effective leadership of local \\
\hline & by impact on student outcomes & provision is secured through \\
\hline & is secured through school & distributed networking \\
\hline & leadership. & and brokerage. \\
\hline
\end{tabular}

Figure 1. A decade of leadership

The vision for learning set out in this white paper will demand the highest qualities of leadership and management from headteachers. The quality of the head often makes the difference between the success or failure of a school. Good heads can transform a school; poor heads can block progress and achievement. It is essential that we have measures in place to strengthen the skills of all new and serving heads. (DfEE, 1997, p. 46)

Headteachers were directed to improve school performance in regard to national testing, and implementing national reforms, because 'schools must take responsibility for their own improvement' (Standards and Effectiveness Unit/DfEE, 1997, p. 4). Research commissioned by OfSTED had promoted 'professional leadership' together with 'shared vision and goals' as important in school 
effectiveness (e.g. Sammons et al., 1995), and the processes involved in shifting a school from 'cruising' to 'moving' had been well documented (e.g. Stoll and Fink, 1996). A former advisor describes the importance of headteachers in the reform process as the 'centrepiece' or 'lynchpin of the reforms', and a Minister summed it up by saying that, 'we always knew we couldn't do what we wanted in education unless we turned round leadership'.

Examining a decade of policy documents shows that headteachers were given the responsibility to implement reform and were accountable for the resulting student outcomes:

- Set, monitor and evaluate targets on student performance (DfEE, 1997);

- Set, monitor and evaluate targets on teacher performance (DfEE, 1998);

- Introduce the national literacy and numeracy strategies (DfEE, 1997);

- Develop range of provision through extended school services (DfES, 2005a);

- Remodelling the school workforce (Blunkett, 2001; DfES, 2002; Morris, 2001).

Through drawing on particular knowledge claims headteachers were legitimised in this reform process as transformational leaders:

All the evidence shows that heads are the key to a school's success. All schools need a leader who creates a sense of purpose and direction, sets high expectations of staff and pupils, focuses on improving teaching and learning, monitors performance and motivates the staff to give of their best. The best heads are as good at leadership as the best leaders in any other sector, including business. The challenge is to create the rewards, training and support to attract, retain and develop many more heads of this calibre. (DfEE, 1998, p. 22)

The pace and requirements of the external reforms meant that New Labour gave recognition to school improvement research that retained the primacy of the single directly accountable leader, but advocated the involvement of others (variously known as the Leadership Team, Middle Leadership, Teacher Leadership) through distributed leadership as a hybrid of transformational leadership (e.g. Harris and Lambert, 2003; OfSTED, 1998).

In order to ensure that the transformational model (and hybrids) was codified and transmitted to headteachers, New Labour did two things: first, it asked the then Teacher Training Agency (TTA, now 
Training and Development Agency) to produce National Standards for Headteachers (TTA, 1998) that could be used in training and accreditation. These standards were revised in 2004 where the job of the headteacher to implement reforms was made explicit (DfES, 2004a). Second, a training framework was established by moving national programmes developed by the previous Conservative government, such as the National Professional Qualification for Headship (NPQH), from the TTA into the NCSL. New Labour regarded the quality of in-service training for existing heads, and particularly the training offered to those prior to taking up headship, as inadequate, where one former Civil Servant described it as 'patchy'. The discourse seemed to be that 'effective' school leadership could not be left to 'chance' where the individual headteacher could choose whether or not to undertake a local authority or higher education course, but required regulated training and hence significant financial investment. Another civil servant encapsulates this:

School Leadership was something that was really, really important and it was something that the government had to invest in. And it wasn't just going to happen naturally; we needed to do something to kind of help schools improve. I don't think that was coming from a place which said all school leaders are dreadful and we're in crisis. I think it was coming from ... education's absolutely at the heart of New Labour's agenda, Tony Blair's 'education, education, education'.

New Labour wanted training to be brought together within a 'branded' coherent framework (NCSL, 2001) and housed within a 'national' college. The ideas about the College varied with discussions about it being 'virtual' but what won the day was the symbolic importance of an iconic building that would send out the message that headteachers were worth the investment.

\section{EfFective LeAdership}

As Figure 1 illustrates, after a decade the primacy of leadership and the importance of the NCSL remained strong (see DfES, 2004b). New Labour encouraged headteachers to take on the New Labour mantle by: first, working within the Standards and Effectiveness Unit or the Innovations Unit at the Ministry and/or taking up roles within the NCSL; second, taking on the role as Principal of an Academy where individual philanthropists or consortia can control the curriculum and the employment conditions of the workforce (DfES, 2005b; Woods et al., 2007); third, demanding faster change within the New 
Labour strategy, and so headteachers are being asked to advise and influence change as systemic leaders (DfES, 2005b); fourth, replicating the achievements of 'successful' headteachers within the locality either through secondment, or more recently through Federations where schools share an 'executive' headteacher (DfES, 2005b). Ten years on, the effective leadership of centralised reform within the locality remains central to the New Labour agenda, but what is emerging, as illustrated in Figure 1, is a reworking of who might exercise such leadership within the system. The phrase 'effective leadership' is increasingly used (see DfES, 2004b), and the recent PricewaterhouseCoopers (DfES/PwC, 2007) report asks whether the person who is leading and exercising leadership within or for a school, an academy, a federation, or a system, needs to have qualified teacher status (QTS): 'there should be no barriers for individuals with the relevant skills to take on the leadership role as long as there is always a senior qualified teacher on the team to act as the 'lead learner' and direct teaching and learning within the institution' (p. 111). Hence the custom and practice of the headteacher being a qualified teacher is removed, and the status of teaching is downgraded in comparison to generic leadership skills and attributes (see Gunter, 2007).

This needs to be put into context because it is a response to a number of problems that had to be faced up to: first, the ability of headteachers to be super heads and turn a school around from failing to effective remains problematic. The 'Fresh Start' scheme with schools closing and then reopening under a new headteacher and staff had variable results with highly publicised resignations of headteachers (Gunter, 2001). Second, the supply of new headteachers through the NCSL training programmes is not being delivered to meet demand. Third, there is research which shows that alternative narratives to that promoted by New Labour are in play, not least that headteachers - particularly experienced ones - exercise professionality in regard to how reforms and guidance are interpreted and engaged with (Forrester and Gunter, 2008; Hollins et al., 2006; Raffo and Gunter, 2008). Fourth, while there have been claims that headteacher leadership is directly related to student outcomes, the government commissioned Leithwood and Levin (2005) to develop a measurement model, and they reported on the mediated impact of headteachers through teachers working directly with students. Hence New Labour faced challenges in ways that emphasised the need to give attention to productive teaching and learning, the prime role of teachers within pedagogic relationships, and the social mix of the communities in which schools are located (Gunter, 2005; Lingard et al., 2003; Thrupp, 1999). 
Concurrent with these emergent realities, New Labour reoriented public services through Every Child Matters (ECM) (DfES, 2003) and so questioned the status and role of the headteacher as teacher. Under ECM the child is put at the centre of provision for education, welfare, health and security, and can access education alongside other services from 'a community campus' (DfES/PwC, 2007, p. 108) in ways that are personalised and responsive. By focusing on children's services with parents as the driving force for improvement in the exercise of choice (DfES, 2004b, 2005b) then there are different forms of provider (state, state-private partnerships, private); and different forms of provision (religious denominational schools, business/philanthropic academies, parental groups, home tutoring, state schools). What is emerging is a further extension of site-based management from 1988 that New Labour inherited in 1997, based on effective leaders from the public, private and voluntary sectors. So leadership is understood in terms of government ensuring sufficient numbers of those with leadership skills who can be attracted to lead local provision of a range of services; as one civil servant stated: 'we are doing all we can to enable schools to recruit and retain the best quality school leaders that they have'. This has been embraced by NCSL Centre Directors based in Universities and who are contracted to deliver highly trained and reform ready leaders. One said: 'I think we will see increasingly with the Every Child Matters agenda new leaders of community organisations who could well be from the health service or social services, they won't be a teacher, but under them they would have the director of studies or whatever'.

\section{Conceptualising the School Leadership Policy Network}

New Labour public policy has drawn upon, sustained and developed a form of knowledge, a network of knowers, and a preferred approach to knowing, in order to bring about change in the public domain. The direct modernisation of headteachers into effective school leaders from 1997 is an example of what Hood et al. identify as a 'domain of risk' (2004, p. 5) where New Labour worked to minimise or even eradicate the hazard of professional educational judgement at local level, and had to marginalise those in the Universities who undertook research and critical conceptualisations of policy. Our data show that what is in play is what Hood et al. describe as a 'risk regulation regime' (2004, p. 8) where the nature, scope and type of perceived risk are created through a "complex of institutional geography, rules, practice, and animating ideas' (p. 9). Our reading of the data shows how associations of people were 
formed and developed as a school leadership policy network in order to handle the risk. Notably there is evidence of what Kingdon (2003) identifies as policy entrepreneurs who cluster around the New Labour agenda of reform: "the list of subjects or problems to which governmental officials, and people outside of government closely associated with those officials, are paying some serious attention at any given time' (p. 3). The configuration and promotion of leadership by New Labour is related to those who present themselves as knowers in ways that enable risky reform to be secured without taking the risk of involving a range of people (e.g. teachers, local authority personnel) who might create alternatives to those reforms. A network emerged including ministers, civil servants, members of non-departmental public bodies (NDPBs) such as the NCSL, directors of training centres in universities, advisors from schools and universities, and private consultants, many of whom have a shared professional knowledge as former practitioners, and so are disposed to know and understand the post-1988 world, not least the logic of a school as a firm.

These seemingly disparate people position themselves in ways to take advantage of a window that opens (Kingdon, 2003). Their knowledge and ways of knowing can provide evidence, language and distinction to legitimise the types of change and the urgency of the reform imperative. What holds people from different sites together is that they have a "willingness to invest their resources - time, energy, reputation, and sometimes money - in the hope of a future return' (p. 122). The 'return' is varied from policy impact, status, and business success. We intend to focus on private sector consultants who work in a range of ways with ministers, civil servants, and advisors employed in Whitehall or in non-departmental public bodies such as the NCSL. By illustrating this particular contribution to the school leadership policy network we can reveal aspects of the policymaking process that are rarely talked or written about. For example, a consultant describes ways of working that are not normally made public:

I've always seen myself as being a person who was committed to the field of School Improvement, School Effectiveness, School Reform and the leadership which underpins this work. Therefore, always committed to the knowledge base around that work. So I suppose in stark terms that was the content knowledge. The question then is how do you use the content knowledge? Some research it, some write it, some profess it. I always wanted to facilitate it. So, my argument was that if you had the content 
knowledge and you fully inducted yourself into the work and you did that in a variety of different ways, then what form of expression would you give to it? And I discovered that the area that increasingly was being opened up was, at one level, strategy. So you could see how that knowledge base could inform strategy. Therefore, you could get involved in the policy formulation phase in really interesting ways. Then I think, there was a sense in which you thought to yourself, 'yes, but there's not much point in that unless you're actually connecting people and ideas' and communicating. And it's through a range of activities that you could broadly define as being professional learning, consultations and professional development opportunities, right from big ticket events through to onsite work [...]. If you are able to operate in that area, you could bring research and practice together in ways that were brokering those connections [...]. Brokers is the most recent expression around this sort of stuff, boundary riders. I don't think it's a set of roles that has been explored, perhaps as much as it might, but part of the reason is because it's not a set of activities that are always well understood, because by definition, 'success' means that it's less visible, deliberately so. It is highly tactical, so therefore it's of a different order. And, to be at the sharp end of it, it practises some arts that are not ones that people necessarily want to reveal. Right. So it's a funny game to be in.

Private sector consultants variously are involved in: contract research; public events that launch policy strategies; are members of NDPB structures; win contracts to deliver reform strategies; and act as trainers on national programmes. This is illustrated by a private consultant:

We're a commercial organisation, yes we charge quite a lot for what we do, but I think on the particular bit of the business that I work on [...] we bring our own style of research to government [...]. We tend to do things a bit quicker [than academic organisations] [...]. Our reports, they generally tend to be reasonably well written and written in plain English and addressing issues that policy makers are interested in. So they tend to be quite practical and that sort of thing [...]. I'm quite proud of some of the policy and research work that we've done.

As consultants they might be regarded, as one did, as 'a bridge between the research community in all senses, and the profession' where they work on the 'border' between research and practice translating 'high quality research done by universities ... into means by which it can inform practice in schools'. This may also involve 
taking aspects of academic research perceived as relevant to practitioners and creating a useable product from it. The consultant explains this:

People in the academic world haven't got the slightest idea who we are or what we do and I think some of them view us with suspicion, and they don't really need to, most of the time we're not competing for the same funds or anything. But we don't write for academic research journals, there's no reason why we would; peer review means nothing to us. [...] We try and connect with the academic world closely through the relationships with the researchers whose work we're turning round, and we never ever produce anything that we haven't agreed with the authors and the feedback we get is widely enthusiastic most of the time. [...] But it's because we're focused on the use, but you can't understand use if you're not also understanding the creation process and its application, interpretation process. To understand use is to understand learning. So we're just completely fixed on learning really, like everybody else in education.

Such brokerage may be where consultants occupy a position that enables them to capitalise upon (including generating new business) and consequentially promote New Labour's agenda for school leadership. This might include working directly with school leaders through leadership training, conferences, producing papers and publications and a whole raft of activities such as the development of products using digital media. For example, the same consultant shows how supply and demand operates regarding how schools perceive the need for training and information and how this links with business provision:

Most of our clients are government agencies or large professional associations [...]. I think we've been able to be very successful in keeping the work going, not withstanding the change in commissioning policy context, because so many policy makers were active and interested and because it was an issue that is just on every school's mind. We've run probably sixty events since last April. All on a commission basis, people asking us, not us running events and saying, 'will you come.' We must have worked with over five thousand people; mainly school heads, deputy heads. And if we ran events I'm sure we could fill halls to the rafters. Because that particular thing had this incredibly solid research core and an incredibly strong need out there, meeting in the middle.

There is a 'carry over' of being a school leadership policy network insider into business generation. A different private consultant states: 
I'm busier than I've ever been in my life. [...] The first area is work for the National College [...] and then the bulk of my time now is spent working with schools and local authorities and I would guess perhaps fifty or sixty per cent of my time.

Advisors, consultants, members of government agencies, work the discourse by communicating directly with practitioners in order to spread the New Labour disposition towards reform implementation and they communicate back into Whitehall how things are 'on the ground', and within this they generate new business opportunities. Overall, what they do is to package and repackage existing ideas into something that is 'new', and so under New Labour school leadership, and the currently emerging effective leadership, is a recombining of inherited strategies (headteacher as a trained leader, a disposition for business leadership) with National Curriculum strategies for literacy and numeracy (targets, performance related pay, and inspection).

Kingdon (2003) identifies three main motives for this interconnectivity within policy: first, 'the promotion of personal interests' (p. 123) where association is through the material gain of keeping your job if you are in government and winning contracts from those who are in the private sector. In 1997 Ministers clearly were under pressure to secure promise changes, and so they brought people in who trusted to deliver. Some had delivered as advisors and consultants under the previous Thatcherite governments, and they presented themselves as apolitical and hence capable of serving as enthusiastic implementers.

Second, 'they want to promote their values, or affect the shape of public policy' (p. 123), and the policy and oral texts show that there is a clear commitment to leaders and leadership by the New Labour administration. The interviewees talked about how they have a 'can do' orientation, and there is a sense that they are proactive with a tried and tested approach which means they secure contracts, and/or they are responsive to policy requests; as one consultant said about training contracts: '... and so ten years ago it would have been on monitoring and evaluation, on appraisal, on all the routine management things. Today it's about values, today it's about learning, today it's about spirituality and so on'. Not all respondents agree with the amount and type of central direction of schooling or the models of leadership they are located and implicated within. A number of advisors and consultants talked about how they had lived with the 'heroic' model of the headteacher as transformational leader, and picked away at it, waited patiently, and looked for opportunities to influence the model. Words such as 'distributed', 'community', 
and 'shared' were used to make leadership more appropriate for schools, but they do not challenge the underlying assumption of the single chief executive. They made an uncongenial model work.

Third, 'policy groupies ... enjoy advocacy, they enjoy being at or near the seat of power, they enjoy being part of the action' (p. 123), and there is evidence that those who have been brought into Whitehall or its agencies, from schools, universities, local authorities as advisors, or are in private companies, do get a buzz from being within this network, and how they are different as a result of not being within an institution such as a school of education in a university, or a local authority. For example, one private consultant states:

The more I hear from my colleagues in HE, the more I'm glad I'm not part of it. I think things like the Research Assessment Exercise are ridiculous, absolutely ridiculous the way it's gone on [...]. So I don't want to be part of the Research Assessment Exercise. At one point people were trying to recruit me to get all my publications on board, and that happened at a couple of universities who were interested in trying to do that. But I feel I have total freedom as a freelance consultant, I can choose which projects I want to do, I can choose who I want to work with, I will only work with colleagues who I respect [...] I choose who I want to work with and as an independent I have complete freedom.

We were given the names of three people by a whole range of respondents in Whitehall, the private sector and universities, who together were and continue to be very influential in the design and delivery of leadership. The close to power buzz is illustrated by one of the three who recognises their role:

... we wouldn't be where we are in this country in terms of leading the world on leadership and education if it hadn't been for people like [name] and me pushing, campaigning, lobbying, persuading, influencing for the last ten years, it's, you know, so much of the ground work, and [name] was in that too, you know, the three of us ... we were consulted in terms of whether there should even be a National College to start with.

This is illustrative of a delivery disposition which permeates New Labour written and oral texts. The language and intention of policy is to secure reform through a logic of practice based on, in Bourdieu (2000) terms, a doxa of investment and accountability. This disposition is revealed by policy entrepreneurs positioned in the 'big tent' and it is used by them to distinguish from the 'enemies' who are kept outside (Hyman, 2005, p. 76). Those regarded as unmodern (in 
universities and local government) are excluded and are positioned as disconnected from practice. Hence the demands of neo-liberalism for the school to be a firm is enabled by knowledge produced and legitimised by those who work in firms.

\section{Conclusion}

The model in play in education policy in England is that of the single person as organisational leader. This person is responsible locally for the delivery of national policy, and they are accountable directly to government for outcomes. While there has been rhetoric around, and training provided for, hybrids such as 'distributed' and 'total' leadership, the primacy of the single person remains, with distribution coming downward, and used as a form of sophisticated delegation and technical job redesign (Gunter, 2005).

At the start of the New Labour decade the headteacher as the commonsense school leader was unreflexively accepted as the means by which rapid change could be transmitted, enacted and measured. As New Labour moves into the second decade, a combination of reforms embedded in Every Child Matters together with the problematics of headteachers as leaders (i.e. insufficient in numbers, and concerns about the embeddedness of professional autonomy) has led to a generic form of effective leadership emerging as a means by which those without QTS might be attracted to the chief executive role and leading local provision of public services. While this widening of the recruitment pool could be risky, this is minimised by private sector knowledge, skills and attributes which are seen as consistent with the New Labour delivery disposition. Performance management maintains the focus on outcomes, and delivery is through commonsense management strategies (see Barber, 2007). The slow creep of the label of 'Principal' is part of this process, along with the remodelling of 'teacher' as a member of a children's workforce. We have shown and argued that these developments are based on a narrow form of knowledge, and are promoted by people from a range of institutions, who share similar dispositions and who have positioned themselves as policy entrepreneurs recombining old ideas about the normality of leadership into new packages of training and ways of working. New Labour took the risk of reform through minimising the risk at local level to securing target compliance. Those drawn into the school leadership policy network offloaded the risks of investment through formal and informal contracts, and generated new business, network connections and products. 


\section{ACKNOWLEDGEMENTS}

The research on which this paper is based was funded by the ESRC through the Knowledge Production in Educational Leadership Project 2006-2007 (ESRC RES-000-23-1192). We would like to thank the ESRC for supporting this research, and we are deeply grateful to the people from all parts of the education system who have told us their stories and participated by giving generously of their time. We would like to thank the members of the Project Advisory Group for their engagement with the research and for the productive dialogue.

\section{REFERENCES}

BALL, S.J. (1990) Politics and Policymaking in Education: Explorations in Policy Sociology (London, Routledge).

BALL, S.J. (1994) Some reflections on policy theory: a brief response to Hatcher and Troyna, Journal of Education Policy, 9 (2), 171-182.

BALL, S.J. (1995) Intellectuals or technicians? The urgent role of theory in educational studies, British Journal of Educational Studies, 43 (3), 255-271.

BALL, S.J. (2007) Education PLC (London, Routledge).

BARBER, M. (2007) Instruction To Deliver. Tony Blair, the Public Services and the Challenge of Achieving Targets (London, Politico's Publishing).

BLUNKETT, D. (2001) The Challenges of Improving Schools (London, DFES). Speech to the IPPR Seminar, 1 May. Available online at: www.dfee.gov.uk/ dfee_speeches/01_05_01/index.shtml (accessed 20 January 2003).

BLUNKETT, D. (2006) The Blunkett Tapes: My Life in the Bear Pit (London, Bloomsbury).

BOURDIEU, P. (1990) In Other Words (Cambridge, Polity Press in association with Blackwell).

BOURDIEU, P. (2000) Pascalian Meditations (Cambridge, Polity Press).

CHITTY, C. (2004) Education Policy in Britain (Basingstoke, Palgrave Macmillan).

CURRIE, G., BOYETT, I. and SUHOMLINOVA, O. (2005) Transformational leadership within secondary schools in England. A panacea for organizational ills? Public Administration, 83 (2), 265-296.

DEEM, R., BREHONY, K.J. and HEATH, S. (1995) Active Citizenship and the Governing of Schools (Buckingham, Open University Press).

DES (1985) Better Schools White Paper, Cm 9469 (London, HMSO).

DfEE (1997) Excellence in Schools, Cm 2681 (London, The Stationery Office).

DfEE (1998) Teachers: Meeting the Challenge of Change, Cm 4164 (London, DfEE).

DfES (2002) Time for Standards: Reforming the School Workforce (London, DfES).

DfES (2003) Every Child Matters, Cm 5860 (London, DfES).

DfES (2004a) National Standards for Headteachers (London, DfES).

DfES (2004b) Five Year Strategy for Children and Learners White Paper, Cm 6272 (London, DfES).

DfES (2005a) Extended Schools Prospectus (London, DfES).

DfES (2005b) Higher Standards, Better Schools for All, More Choice for Parents and Pupils, Cm 6677 (London, HM Government).

DfES/PricewaterhouseCoopers (2007) Independent Study into School Leadership (London, DfES). 
FORRESTER, G. and GUNTER, H.M. (2008 forthcoming) School leaders: meeting the challenge of change. In G. CHAPMAN and H.M. GUNTER (Eds) Radical Reforms: a Decade of Educational Reform (London, Routledge).

GRACE, G. (1995) School Leadership: Beyond Educational Management (London, Falmer Press).

GUNTER, H.M. (2001) Leaders and Leadership in Education (London, Paul Chapman).

GUNTER, H.M. (2005) Leading Teachers (London, Continuum).

GUNTER, H.M. (2007) Remodelling the school workforce in England: a study in tyranny? Journal of Critical Education Policy Studies, 5 (1).

GUNTER, H.M. and FITZGERALD, T. (2008) The future of leadership research, article under review.

HARRIS, A. and LAMBERT, L. (2003) Building Leadership Capacity for School Improvement (Maidenhead, Open University Press).

HOLLINS, K., GUNTER, H.M. and THOMSON, P. (2006) Living improvement: a case study of a secondary school in England, Improving Schools, 9 (2), 141-152.

HOOD, C., ROTHSTEIN, H. and BALDWIN, R. (2004) The Government of Risk (Oxford, Oxford University Press).

HOPKINS, D. (2001) 'Think Tank' Report to Governing Council (Nottingham, NCSL).

HYMAN, P. (2005) One Out of Ten, From Downing Street Vision to Classroom Reality (London, Vintage).

JOSEPH, K. (1984) Speech by the Rt Hon Sir Keith Joseph, Secretary of State for Education and Science, at the North of England Education Conference, Sheffield, on Friday 6 January 1984, Oxford Review of Education, 10 (2), 137-146.

KELLY, R. (2004) Remit Letter to the National College for School Leadership, Priorities 2005-2006, 20 December (London, DfES).

KINGDON, J. (2003) Agendas, Alternatives and Public Policies (2nd edn.) (New York, Longman).

LEITHWOOD, K. and LEVIN, B. (2005) Assessing School Leader and Leadership Programme Effects on Pupil Learning (London, DfES).

LEITHWOOD, K., DAY, C., SAMMONS, P., HARRIS, A. and HOPKINS, D. (2006) Seven Strong Claims about Successful School Leadership (Nottingham, NCSL).

LINGARD, B., HAYES, D., MILLS, M. and CHRISTIE, P. (2003) Leading Learning (Maidenhead, Open University Press).

MORRIS, E. (2001) Professionalism and Trust, Social Market Foundation Speech (London, DfES).

NCSL (2001) Leadership Development Framework (Nottingham, NCSL).

OfSTED (1998) School Evaluation Matters (London, OfSTED).

OZGA, J. (1987) Studying education policy through the lives of the policymakers: an attempt to close the macro-micro gap. In S. WALKER and L. BARTON (Eds) Changing Policies, Changing Teachers: New Directions for Schooling? (Milton Keynes, Open University Press).

OZGA, J. (2000) Policy Research in Educational Settings (Buckingham, Open University Press).

RAFFO, C. and GUNTER, H.M. (2008) Leading schools to promote social inclusion: developing a conceptual framework for analysing research, policy and practice, Journal of Education Policy. In press.

SAMMONS, P., HILLMAN, J. and MORTIMORE, P. (1995) Key Characteristics of Effective Schools: a Review of School Effectiveness Research (London, Institute of Education for the Office of Standards in Education).

STANDARDS AND EFFECTIVENESS UNIT/DfEE (1997) From Targets to Action (London, DfEE). 
STOLL, L. and FINK, D. (1996) Changing Our Schools: Linking School Effectiveness and Improvement (Buckingham, Open University Press).

THRUPP, M. (1999) Schools Making a Difference: Lets Be Realistic (Buckingham, Open University Press).

THRUPP, M. and WILLMOTT, R. (2003) Education Management in Managerialist Times (Maidenhead, Open University Press).

TOMLINSON, S. (2005) Education in a Post-Welfare Society (Maidenhead, Open University Press).

TTA (1998) National Standards for Headteachers (London, TTA).

WEINDLING, D. (2004) Funding for Research on School Leadership (Nottingham, NCSL). Available online at: www.ncsl.org.uk (accessed 18 May 2007).

WOODS, P., WOODS, G. and GUNTER, H.M. (2007) Academy schools and entrepreneurialism in education, Journal of Education Policy, 22 (2), 263-285.

Correspondence

Helen Gunter

University of Manchester

School of Education

Oxford Road

Manchester M13 9PL

E-mail: helen.gunter@manchester.ac.uk 